\title{
Aplikasi Pendaftaran Online Berdasarkan Sistem Zonasi Berbasis Sistem Informasi Geografis (Studi Kasus SMK TI Tunas Harapan Bekasi)
}

\author{
Heri Setiawan ${ }^{1}$, Malikus Sumadyo ${ }^{1}$, Rahmadya Trias Handayanto 1,
}

* Korespondensi: e-mail: rahmadya.trias@gmail.com

1 Program Studi Teknik Komputer Fakultas Teknik, Universitas Islam 45; Jl. Cut Meutia No. 83, Bekasi Timur, Bekasi, Jawa Barat 17113. Telp: 021-8801027, 8802015, Fax: 021-8801192 e-mail: heritkom0004@gmail.com, malikus.sumadyo@gmail.com rahmadya.trias@gmail.com.

Submitted: 2 Maret 2020 Revised: 23 Maret 2020 Accepted: 13 April 2020 Published: 20 Mei 2020

\section{Abstract}

The Bekasi City Government uses a zoning system for the registration of prospective new students, especially those applied for junior and senior high schools. For this policy, prospective students are not free to register at the desired school because they must be based on the distance from home to school. This also often triggers academic-based discrimination that often arises in the community. The purpose of this research is to make an application design in one of the schools in Bekasi regarding the design of an online registration application based on the Geographic Information System (GIS). With the application design that is following the data and facts obtained from the analysis of this system, it will be able to provide the final decision of accepting new students at the SMK TI Tunas Harapan school, as case study. Therefore, the information system can be managed in the future and provide solutions to various problems.

Keywords: Android, Website, Application, GIS, Zoning

\section{Abstrak}

Pemerintah Kota Bekasi menggunakan sistem zonasi untuk pendaftaran calon peserta didik baru khususnya diberlakukan untuk tingkat SMP dan SMA juga yang sederajat. Atas kebijakan itu, calon peserta didik tidak leluasa untuk mendaftar ke sekolah yang diinginkan karna harus berdasarkan jarak dari rumah ke sekolah. Hal ini juga sering memicu diskrimasi berbasis akademis yang kerap muncul di masyarakat. Tujuan dari penelitian ini membuat aplikasi merancang suatu rancangan aplikasi di salah satu sekolah di Kota Bekasi mengenai perancangan aplikasi pendaftaran online berdasarkan sistem zonasi berbasis Sistem Informasi Geografis (SIG) studi kasus SMK TI Tunas Harapan. Dengan adanya rancangan aplikasi yang sesuai dengan data dan fakta yang didapatkan dari analasis sistem ini, akan mampu memberikan informasi beserta keputusan akhir dalam proses penerimaan peserta didik baru di sekolah SMK TI Tunas Harapan sehingga kedepannya sistem informasi tersebut dapat dikelola dan memberikan solusi atas berbagai macam permasalahan yang terjadi.

Kata kunci: Android, Website, Aplikasi, SIG, Zonasi.

\section{Pendahuluan}

Berdasarkan peraturan Permendikbud no. 14 tahun 2018 tentang penerimaan siswa didik baru, pasal 16 ayat 1 dalam sistem zonasi yang menyatakan bahwa sekolah yang diselenggarakan oleh pemerintah daerah wajib menerima calon peserta didik yang berdomisili pada radius zona terdekat dari sekolah paling sedikit sebesar $90 \%$ dari total jumlah keseluruhan peserta didik yang diterima. Ini berarti, sekolah hanya memiliki kuota $10 \%$ untuk menerima peserta didik dari luar zonanya. Radius zona akan ditentukan oleh pemerintah daerah, sesuai dengan kondisi dan daya tampung di daerah masing-masing.

Pemerintah Kota Bekasi menggunakan sistem zonasi untuk pendaftaran calon peserta didik baru khususnya diberlakukan untuk tingkat SMP dan SMA juga yang sederajat. Atas 
kebijakan itu, calon peserta didik tidak leluasa untuk mendaftar ke sekolah yang diinginkan karna harus berdasarkan jarak dari rumah ke sekolah. Hal ini juga sering memicu diskrimasi berbasis akademis yang kerap muncul di masyarakat. Kebijakan memilih sekolah berdasarkan zonasi ini mengarahkan calon peserta didik memilih sekolah yang memiliki jarak tempuh maksimal radius 5 kilometer dari wilayah tempat tinggal calon peserta didik tersebut. Kebijakan memilih sekolah berbasis wilayah tempat tinggal peserta didik merupakan upaya kontribusi bidang pendidikan untuk mendukung tata kota. Salah satunya adalah mengurangi kemacetan lalu lintas di Kota Bekasi, dan dengan adanya kebijakan tersebut mampu mendorong pemerataan mutu di sekolah-sekolah seluruh wilayah Kota Bekasi.

Pendidikan sebagai salah satu wahana pembentuk karakter bangsa, pembentukan pribadi juga untuk mempersiapkan tenaga kerja merupakan salah satu komponen penting dalam melanjutkan regenerasi kehidupan yang lebih baik lagi. Tempat berlangsungnya proses pendidikan baik itu di sekolah maupun perguruan tinggi adalah lokasi penting dimana para "Pembangun Bangsa" diharapkan dapat berjuang untuk menimba ilmu yang sebaik-baiknya juga setinggi-tingginya. Seiring dengan derasnya tantangan global, tantangan dunia pendidikan pun menjadi semakin besar, hal ini yang mendorong para siswa untuk mendapatkan prestasi terbaik. Namun, dunia pendidikan di Indonesia masih memiliki beberapa kendala yang berkaitan dengan mutu dan kualitas pendidikan serta pelaksanaan penerimaan peserta didik baru pun sering mendapatkan kendala dalam sistem penerimaan yang diterapkan oleh pemerintah setempat.

Dalam penelitian ini penulis akan melakukan analisis serta merancang suatu rancangan aplikasi di salah satu sekolah di Kota Bekasi mengenai perancangan aplikasi pendaftaran online berdasarkan sistem zonasi berbasis GIS studi kasus SMK TI - Tunas Harapan. Dengan adanya rancangan aplikasi yang sesuai dengan data dan fakta yang didapatkan dari analasis sistem ini, akan mampu memberikan informasi beserta keputusan akhir dalam proses penerimaan peserta didik baru di sekolah SMK TI - Tunas Harapan sehingga kedepannya sistem informasi tersebut dapat dikelola dan memberikan solusi atas berbagai macam permasalahan yang terjadi.

Berdasarkan latar belakang, maka dapat dibuat rumusan masalah yaitu bagaimana membuat aplikasi pendaftaran online berdasarkan sistem zonasi berbasis GIS studi kasus SMK TI Tunas Harapan.

Berdasarkan rumusan masalah yang telah dijelaskan di atas, maka ditetapkan batasan masalah sebagai berikut: 1) Aplikasi ini tidak menyangkut dengan pembayaran formulir pendaftaran dan biaya administrasi sekolah. 2). Perangkat lunak yang digunakan untuk membangun aplikasi ini adalah Android Studio untuk pembuatan form pendaftaran dan PHP, MySQL untuk pembuatan website admin. 3) Aplikasi pendaftaran online yang dibangun berbasis mobile dengan sistem operasi Android minimal 2.2. 4) Aplikasi pendaftaran online terbagi menjadi dua tampilan interface yaitu, form pendaftaran Android sebagai tempat calon 
siswa untuk pendaftaran dan website admin sebagai tempat eksekusi proses yang berjalan. 5). Aplikasi hanya dapat digunakan jika terhubung dengan jaringan internet.

Adapun tujuan dari pembuatan aplikasi pendaftaran online ini antara lain adalah: 1) Membuat rancangan aplikasi Android dan website pendaftaran siswa online berbasis GIS berdasarkan sistem zonasi yang dapat digunakan sebagai solusi dari suatu permasalahan yang terjadi sebelumnya, dan 2) Mengimplementasikan rancangan aplikasi Android dan website pendaftaran siswa online berbasis GIS berdasarkan sistem zonasi.

Adapun manfaat dari pembuatan aplikasi pendaftaran online ini antara lain: 1) Calon siswa tidak perlu datang ke sekolah untuk pendaftaran, 2) Mempermudah untuk pengarsipan data dan menentukan calon siswa yang berada dalam radius sistem zonasi, dan 3) Mempermudah dan menghemat waktu pemprosesan pendaftaran.

Perancangan adalah satu kegiatan yang memiliki tujuan untuk mendesain sistem baru yang dapat menyelesaikan masalah-masalah yang dihadapi perusahaan yang diperoleh dari pemilihan alternatif sistem yang terbaik (Hanadi, 2013).

"Aplikasi merupakan paket software yang ditulis oleh orang lain" definisi lain "perangkat lunak aplikasi (aplication software) adalah program yang biasa dipakai oleh pemakai untuk melakukan tugas-tugas yang spesifik; misalnya untuk membuat dokumen, memanipulasi foto, atau membuat laporan keuangan" (Hanadi, 2013).

Android adalah sebuah sistem operasi perangkat mobile berbasis linux yang mencangkup sistem operasi, middleware dan aplikasi. Android menyediakan platform terbuka bagi para pengembang untuk menciptakan aplikasi mereka. Awalnya, Google Inc. membeli Android Inc. yang merupakan pendatang baru yang membuat peranti lunak untuk ponsel atau smartphone. Kemudian untuk mengembangkan Android, dibentuklah Open Handset Alliance, konsorsium dari 34 perusahaan peranti keras, peranti lunak dan telekomunikasi, termasuk Google, HTC, Intel, Motorola, Qualcomm, T-Mobile, dan Nvidia (Juansyah, 2015).

Android studio adalah IDE (Integrated Development Environment) resmi untuk pengembangan aplikasi Android dan bersifat open source atau gratis. Peluncuran Android Studio ini diumumkan oleh Google pada 16 mei 2013 pada event Google I/O Conference untuk tahun 2013. Sejak saat itu, Android Studio mengantikan Eclipse sebagai IDE resmi untuk mengembangkan aplikasi Android. Android studio sendiri dikembangkan berdasarkan IntelliJ IDEA yang mirip dengan Eclipse disertai dengan ADT plugin (Android Development Tools) (Juansyah, 2015).

PHP singkatan dari "PHP: Hypertext Preprocessor". PHP merupakan bahasa berbentuk skrip yang ditempatkan dalam server dan diproses di server. Hasilnya yang dikirimkan ke klien, tempat pemakai menggunakan browser. Dengan menggunakan PHP, website akan lebih interaktif dan dinamis. Artinya, ia dapat membentuk tampilan berdasarkan permintaan terkini. Pada prinsipnya PHP mempuyai fungsi yang sama dengan skrip-skrip seperti ASP, Cold Fusion maupun JSP. Kemudahan lain dari PHP adalah mampu berintegrasi dengan berbagai macam database salah satunya (Sakur, 2011). 
Sistem koordinat kartesian bidang datar dua dimensi, jarak antara dua titik dapat dicari melalui persamaan, $\mathrm{D}=\sqrt{\left(x_{2}-x_{1}\right)^{2}+\left(y_{2}-y_{1}\right)^{2}}$. $\mathrm{D}$ merupakan jarak linier antara dua titik, $x 1$ adalah posisi titik $\mathrm{i}(1,2, \ldots \mathrm{n})$ pada sumbu $\mathrm{x}$, dan $\mathrm{y} 1$ merupakan posisi titik $\mathrm{i}(1,2, \ldots \mathrm{n})$ pada sumbu y. Kesebandingan antara beda antara beda sudut lintang dan bujur dengan beda jarak lurus, maka dapat beda posisi pada koordinat kartesian sebanding dengan beda posisi pada garis lintang dan bujur. Sehingga dari formula diatas kita dapat implementasi menjadi, Jarak $=\sqrt{\left(\text { Lat }_{2}-\text { Lat }_{1}\right)^{2}+\left(\text { Long }_{2}-\text { Long }_{1}\right)^{2}}$. Hasil perhitungan (Jarak) ini masih dalam satuan decimal degree (sesuai dengan format longlat yang dipakai) (Maharani, 2017).

PhpMyAdmin adalah tools yang dapat digunakan dengan mudah untuk memanejemen database MySQL secara visual dan Server MySQL, sehingga kita tidak perlu lagi harus menulis query SQL setiap akan melakukan perintah operasi database. Tools ini cukup populer, karena fasilitas ini didapatkan ketika menginstal paket triad phpMyAdmin, karena termasuk dalam xampp yang sudah di instal. phpMyAdmin juga adalah tools MySQL Client berlisensi Freeware. phpMyAdmin harus dijalanakan di sisi server web dan pada komputer harus tersedia php, karena berbasis web (Nugroho, 2013).

Sistem Informasi Geografis (SIG) atau yang juga dikenal sebagai Geographic Information System (GIS) pertama pada tahun 1960 yang bertujuan untuk menyelesaikan permasalahan geografis. SIG merupakan sistem komputer yang berbasis pada sistem informasi yang digunakan untuk memberikan bentuk digital dan analisis terhadap permukaan geografi bumi yang menyajikan informasi dalam bentuk grafis dengan menggunakan peta sebagai antarmuka. SIG akan memudahkan dalam melihat fenomena kebumian dengan perspektif yang lebih baik dan SIG mampu mengakomodasi penyimpanan, pemrosesan, serta penayangan data spasial digital bahkan integrasi data yang beragam, mulai dari citra satelit, foto udara, peta bahkan data statistik (Erika, 2016).

\section{Metode Penelitian}

Lokasi penelitian kali ini adalah Kota SMK TI Tunas Harapan, Provinsi Jawa Barat. Secara geografis terletak diantara $6^{\circ} 13^{\prime} 56.8^{\prime \prime}$ Lintang Selatan dan $107^{\circ} 00^{`} 42.9^{\prime \prime}$ Bujur Timur.

Adapun bahan dan peralatan yang digunakan dalam penelitian ini adalah sebagai berikut:

Data Spasial yang diperlukan berupa koordinat lokasi, yaitu : 1) Data koordinat $X, Y$ lokasi sekolah, dan 2) Data koordinat $X, Y$ lokasi calon siswa. Selain itu diperlukan jua data Non Spasial yaitu: 1) Foto objek sekolah, dan 2) Data atribut calon siswa.

Perangkat keras yang dibutuhkan dalam penelitian ini antara lain: 1) Laptop ASUS X441N Series dengan spesifikasi Sistem Operasi Windows 10 Home Single Language 64-bit; Prosesor Intel(R) Celeron(TM) CPU N3350@ 1.10GHz 1.10GHz; Memory 4,00GB RAM, 2) Smartphone Mi Note 3 dengan spesifikasi Android Version 9.0.0-Pie; Prosesor SnapDragon 
660, Memory 6GB RAM, Dual Network standby, G-Sensor, GPS satellites. Untuk perangkat lunak adalah XAMPP, Android Studio, Google Maps, Google Chrome, dan Notepad++.

Tahapan penelitian atau yang biasanya disebut dengan flowchart adalah langkahlangkah yang disimbolkan dalam bentuk geometris, beserta urutannya dengan menghubungkan masing-masing langkah tersebut menggunakan tanda panah. Berikut adalah flowchart pekerjaan dalam penelitian ini.

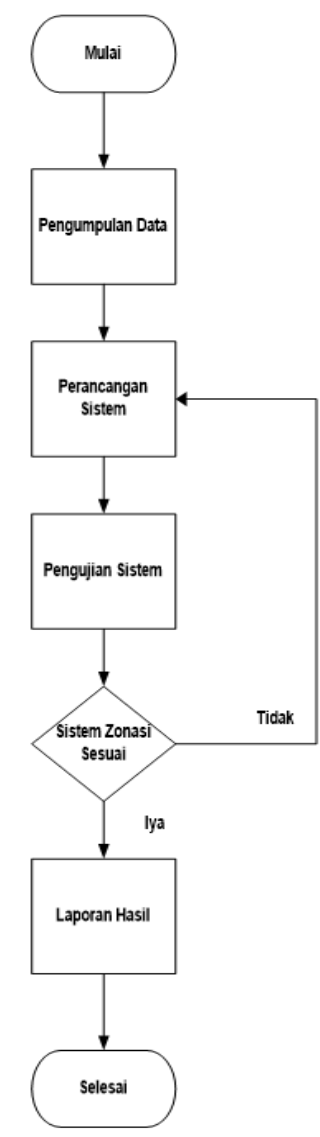

Sumber: Hasil Peneltian (2019)

\section{Gambar 1. Flowchart Tahapan Penelitian}

Tahap pertama, Pengumpulan data, Pada tahap ini mengumpulkan data-data yang akan digunakan dalam penelitian (data spasial dan non spasial). Data spasial yang digunakan adalah alamat sekolah SMK TI - Tunas Harapan, koordinat sekolah, Google Maps API. Dan data non spasial yang digunakan adalah data atribut sekolah. Tahap kedua, Perancangan system, Pada tahap ini pada alamat lokasi sekolah tersebut konversi dengan menggunakan aplikasi Google Maps dan mendapat titik koordinat Latitude dan Longitude lokasi sekolah berupa titik koordinat, $-6.232844^{\circ}, 107.011788^{\circ}$ untuk diproses selanjutnya. Tahap Ketiga, Pengujian system, Pengujian pencarian jarak antara sekolah dan calon siswa menggunakan teori euclidean distance bidang datar dua dimensi, jarak antara dua titik dapat dicari melalui persamaan $\mathrm{D}=\sqrt{\left(x_{2}-x_{1}\right)^{2}+\left(y_{2}-y_{1}\right)^{2}}$. Tahap keempat, Laporan hasil, Pada tahapan 
ini sistem dibuat dengan ketentuan radius 5 kilo meter dari titik koordinat lokasi sekolah ke alamat calon siswa yang terdaftar pada sistem sekolah SMK TI - Tunas Harapan. Tahap akhir dari pengujian sistem ini akan menampilkan hasil output yang berupa data siswa yang telah lolos dari sistem zonasi yang sudah melalui tahapan pengujian sistem zonasi, pada hasil klarifikasi ini berdasarkan dengan ketentuan yang berlaku menurut sistem zonasi sekolah SMK TI - Tunas Harapan.

\section{Hasil dan Pembahasan}

\section{A. Software Requirements Specification (SRS)}

Software Requirements Specification (SRS), sebuah spesifikasi kebutuhan untuk sebuah sistem perangkat lunak, adalah dokumen yang dibuat ketika sebuah perangkat lunak akan dikembangkan. Di dalamnya terdapat penjelasan dari keseluruhan aspek dari sebuah perangkat lunak.

Tabel 1. Kebutuhan Fungsional dan Non-fungsional

\begin{tabular}{|c|c|c|c|c|}
\hline No & Strategic Area & Nilai yang diharapkan & Spesifikasi & Requirment Point \\
\hline 1 & $\begin{array}{l}\text { Perancangan aplikasi pendaftaran } \\
\text { online berdasarkan sistem zonasi } \\
\text { berbasis gis studi kasus SMK TI - } \\
\text { Tunas Harapan }\end{array}$ & $\begin{array}{l}\text { Menghasilkan output berupa } \\
\text { titik koordinat } X, Y \text { calon } \\
\text { siswa/i }\end{array}$ & Fungsional & $\begin{array}{l}\text { Pengelolaan aplikasi } \\
\text { pendaftaran online } \\
\text { pada web admin }\end{array}$ \\
\hline 2 & & $\begin{array}{l}\text { Menghasilkan output berupa } \\
\text { jarak (kilometer) lokasi } \\
\text { sekolah dengan calon siswa/i }\end{array}$ & Fungsional & $\begin{array}{l}\text { Pengelolaan aplikasi } \\
\text { pendaftaran online } \\
\text { pada web admin }\end{array}$ \\
\hline 3 & & $\begin{array}{l}\text { Menghasilkan output berupa } \\
\text { berita }\end{array}$ & Fungsional & $\begin{array}{l}\text { Pengelolaan aplikasi } \\
\text { pendaftaran online } \\
\text { pada aplikasi android }\end{array}$ \\
\hline 4 & & $\begin{array}{l}\text { Menghasilkan output berupa } \\
\text { pengumuman hasil calon } \\
\text { siswa/i }\end{array}$ & Fungsional & $\begin{array}{l}\text { Pengelolaan aplikasi } \\
\text { pendaftaran online } \\
\text { pada aplikasi android }\end{array}$ \\
\hline 5 & & $\begin{array}{l}\text { Mampu menyimpan identitas } \\
\text { yang dibuat oleh Admin }\end{array}$ & Fungsional & $\begin{array}{l}\text { Pengelolaan database } \\
\text { pada aplikasi } \\
\text { pendaftaran online }\end{array}$ \\
\hline
\end{tabular}

Sumber: Hasil Penelitian (2019)

Tabel 2. Identifikasi Aktor

\begin{tabular}{ccc}
\hline No & Aktor & Deskripsi Aktor \\
\hline 1 & Admin & Dapat menambahkan data, mengubah data, menghapus data dan proses data \\
\hline 2 & User & Dapat menambahkan data, melihat hasil data
\end{tabular}

Sumber: Hasil Penelitian (2019)

\section{B. Usecase Diagram}

Diagram ini memperlihatkan himpunan usecase dan aktor-aktor (suatu jenis khusus dari kelas). Diagram ini terutama sangat penting untuk mengorganisasi dan memodelkan perilaku dari suatu sistem yang dibutuhkan serta diharapkan pengguna. Usecase diagram yang 
digunakan pada sistem ini mempunyari 2(dua) sarana untuk admin yaitu website admin dan untuk user aplikasi android.

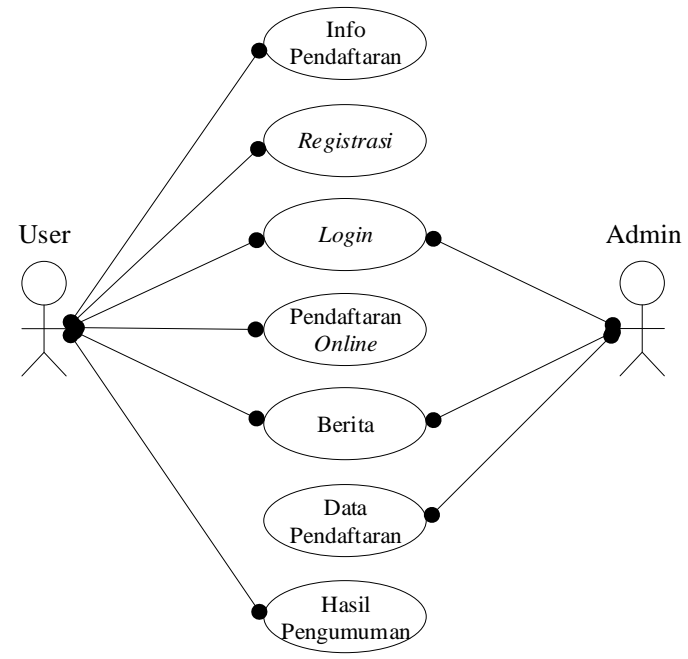

Sumber: Hasil Penelitian (2019)

Gambar 2. Usecase Diagram Pendaftaran Online

\section{Activity Diagram}

Activity diagram memodelkan alur kerja (workflow) sebuah proses bisnis dan urutan aktivitas dalam suatu proses. Diagram ini sangat mirip dengan sebuah flowchart karena dapat dimodelkan sebuah alur kerja dari satu aktivitas ke aktivitas lainnya atau dari satu aktivitas ke dalam keadaan sesaat (state). Activity diagram pada sistem ini seperti gambar berikut.

Pada bagian ini, dijelaskan hasil penelitian dan pada saat yang sama diberikan pembahasan yang komprehensif. Hasil dapat disajikan dalam angka, grafik, tabel dan lain-lain yang membuat pembaca memahami dengan mudah. Pembahasan dapat dibuat dalam beberapa sub-bab.

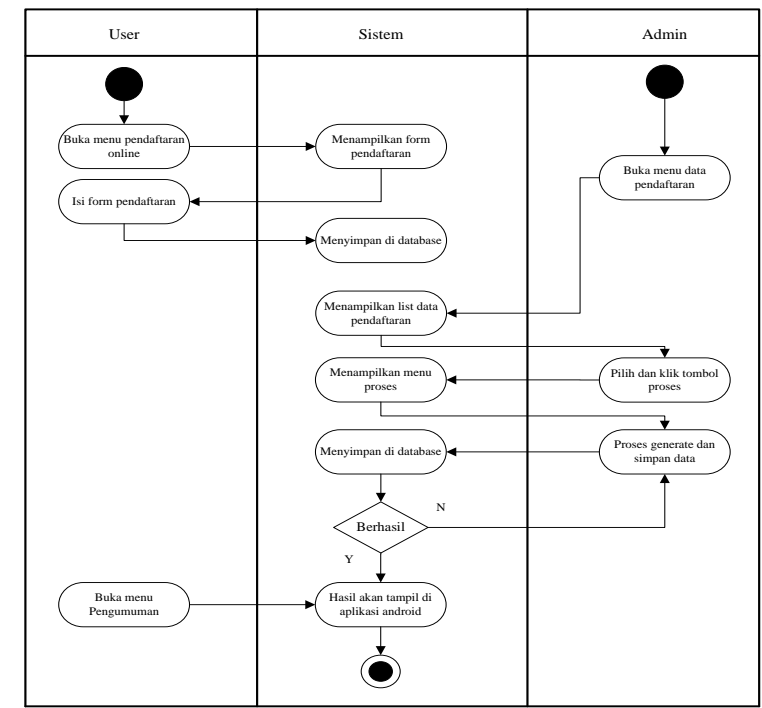

Sumber: Hasil Penelitian (2019)

Gambar 3. Activity Diagram Pendaftaran Online 


\section{Desain Interface Website}

Desain interface website merupakan tampilan awal web yang juga berisi informasi seperti menu home, input berita, data pendaftaran, dan sign out. Berikut pada gambar 3.5 tampilan dari desain interface website.

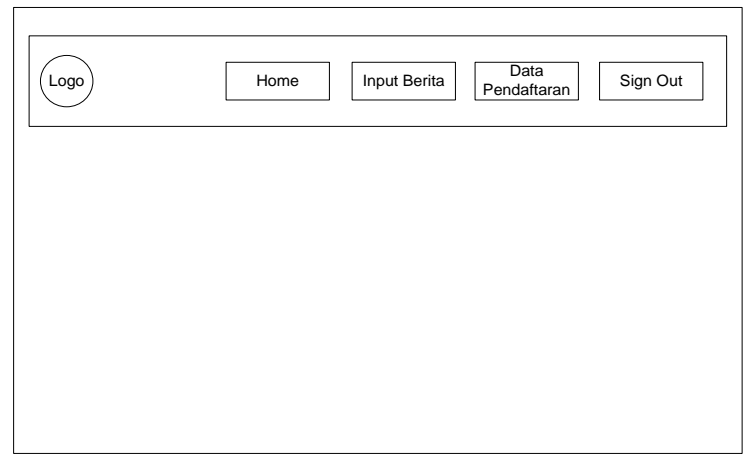

Sumber: Hasil Penelitian (2019)

Gambar 4. Desain Interface Website

Keterangan dari desain interface yang dibuat, sebagai berikut: 1) Logo adalah bagian dari menu website yang dibuat. Logo ini berupa gambar sekolah. 2) Home adalah bagian dari menu website yang dibuat. Menu home ini berisi mengenai informasi mengenai website. 3) Input berita adalah bagian dari menu website yang dibuat. Menu input berita ini menampilkan form untuk membuat berita. 4) Data pendaftaran adalah bagian dari menu website yang dibuat. Menu data pendaftaran ini berisi mengenai informasi calon siswa yang telah mendaftar di sekolah, yang kesemua informasinya dalam bentuk tabel. 5) Sign Out adalah bagian dari menu website yang dibuat. Menu sign out ini berfungsi untuk keluar dari halaman website admin.

\section{E. Desain Interface Android}

Desain interface android merupakan tampilan awal aplikasi yang juga berisi informasi seperti menu home, berita, rincian biaya, pendaftaran, pengumuman, dan logout. Berikut pada gambar 5 tampilan dari desain interface android.

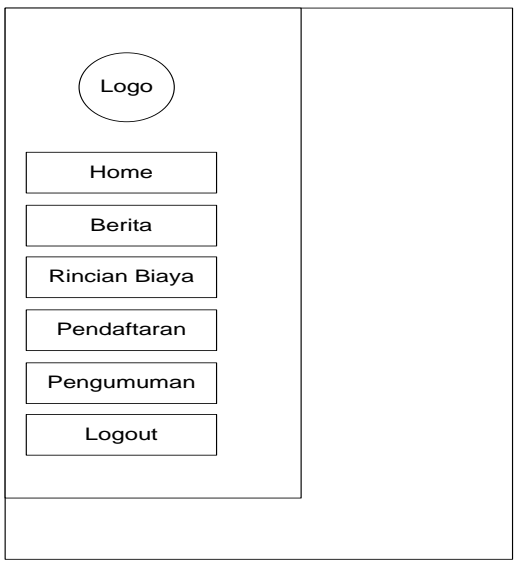

Sumber: Hasil Penelitian (2019)

Gambar 5. Desain Interface Android 
Keterangan dari desain interface yang dibuat, sebagai berikut : 1) Logo adalah bagian dari menu Android yang dibuat. Logo ini berupa gambar sekolah. 2) Home adalah bagian dari menu Android yang dibuat. Menu home ini berisi mengenai informasi mengenai sekolah. 3) Berita adalah bagian dari menu Android yang dibuat. Menu berita ini menampilkan list berita. 4) Rincian biaya adalah bagian dari menu Android yang dibuat. Menu rincian biaya ini berisi mengenai informasi admnistrasi sekolah. 5) Pendaftaran online adalah bagian dari menu android yang dibuat. Menu data pendaftaran online ini berisi form untuk pendaftaran calon siswa pada sekolah. 6) Pengumuman adalah bagian dari menu Android yang dibuat. Menu pengumuman berisi mengenai informasi hasil pengumuman pendaftaran online pada calon siswa. 7) Logout adalah bagian dari menu Android yang dibuat. Menu logout ini berfungsi untuk keluar dari aplikasi android.

Setelah dilakukan perancangan dan penulisan program, maka didapatkan hasil berupa aplikasi pendaftaran online pada SMK TI - Tunas Harapan, aplikasi ini dapat diakses melalui komputer maupun smartphone yang sudah terhubung ke internet, Implementasi antar muka (interface) dan basis data (database) sebagai berikut:

\section{(1) Implementasi Basis Data}

Data yang ditampilkan di dalam aplikasi pendaftaran online pada SMK TI - Tunas Harapan di simpan dalam sebuah tabel pendaftaran yang menyimpan data sebagai berikut.

\begin{tabular}{|c|c|c|c|c|c|c|c|c|}
\hline & Kolom & Jenis & Penyortiran & Atribut & Kosong & Default & Ekstra & Aksi \\
\hline$\square$ & 1 id_pendaftaran & int(11) & & & Tidak & None & AUTO_INCREMENT & Ubah $(2)$ Hapus Selebihnya \\
\hline$\square$ & 2 id_user & $\operatorname{int}(4)$ & & & Ya & NULL & & Ubah $(-)$ Hapus Selebihnya \\
\hline$\square$ & 3 tanggal_pendaftaran & date & & & Ya & NULL & & Ubah (- Hapus Selebihnya $\mathbf{V}$ \\
\hline$\square$ & 4 nama_lengkap & $\operatorname{varchar(100)}$ & latin1_swedish_ci & & $\mathrm{Ya}$ & NULL & & Ubah $(-$ Hapus Selebihnya $\mathbf{}$ \\
\hline$\square$ & 5 nama_panggilan & $\operatorname{varchar}(50)$ & latin1_swedish_ci & & Ya & NULL & & Ubah $($ Hapus Selebihnya $\mathbf{T}$ \\
\hline$\square$ & 6 email & varchar(100) & latin1_swedish_ci & & $\mathrm{Ya}$ & NULL & & $\mathcal{Q}$ Ubah $($ Hapus Selebihnya \\
\hline$\square$ & 7 tempat_lahir & $\operatorname{varchar}(100)$ & latin1_swedish_ci & & Ya & NULL & & $\checkmark$ Ubah $($ Hapus Selebihnya $\mathbf{}$ \\
\hline$\square$ & 8 tanggal_lahir & date & & & Ya & NULL & & $\mathcal{Q}$ Ubah $\odot$ Hapus Selebihnya $\mathbf{}$ \\
\hline$\square$ & 9 jenis_kelamin & $\operatorname{varchar}(40)$ & latin1_swedish_ci & & Ya & NULL & & Ubah () Hapus Selebihnya $\mathbf{\nabla}$ \\
\hline$\square 10$ & 10 nomor_telepon & $\operatorname{varchar}(50)$ & latin1_swedish_ci & & Ya & NULL & & Ubah $($ Hapus Selebihnya $\mathbf{V}$ \\
\hline$\square 11$ & 11 alamat & mediumtext & latin1_swedish_ci & & Ya & NULL & & 2 Ubah $(1)$ Hapus Selebihnya $\mathbf{}$ \\
\hline$\square 12$ & 12 agama & $\operatorname{varchar}(150)$ & latin1_swedish_ci & & $\mathrm{Ya}$ & NULL & & $\mathcal{Q}$ Ubah $(-$ Hapus Selebihnya $\mathbf{}$ \\
\hline$\square 13$ & 13 golongan_darah & $\operatorname{varchar}(50)$ & latin1_swedish_ci & & $\mathrm{Ya}$ & NULL & & $\checkmark$ Ubah $\odot$ Hapus Selebihnya \\
\hline$\square 14$ & 14 asal_sekolah & $\operatorname{varchar}(200)$ & latin1_swedish_ci & & Ya & NULL & & Ubah $(-$ Hapus Selebihnya $\mathbf{}$ \\
\hline$\square 15$ & 15 nomor_ijasah & $\operatorname{varchar}(50)$ & latin1_swedish_ci & & $Y_{a}$ & NULL & & 2 Ubah $(-$ Hapus Selebihnya $\mathbf{\nabla}$ \\
\hline$\square 16$ & 16 ijasah & $\operatorname{varchar}(200)$ & latin1_swedish_ci & & Ya & NULL & & Ubah $\odot$ Hapus Selebihnya $\mathbf{\nabla}$ \\
\hline$\square 17$ & 17 nisn & $\operatorname{varchar}(50)$ & latin1_swedish_ci & & Ya & NULL & & 2 Ubah $(2)$ Hapus Selebihnya $\mathbf{V}$ \\
\hline$\square 18$ & 18 latitude & $\operatorname{varchar}(100)$ & latin1_swedish_ci & & Ya & NULL & & Ubah $(-$ Hapus Selebihnya $\mathbf{V}$ \\
\hline$\square 19$ & 19 longitude & $\operatorname{varchar}(100)$ & latin1_swedish_ci & & $\mathrm{Ya}_{\mathrm{a}}$ & NULL & & $\mathcal{D}$ Ubah $($ Hapus Selebihnya \\
\hline$\square 20$ & 20 jarak & $\operatorname{varchar}(100)$ & latin1_swedish_ci & & Ya & NULL & & $\mathcal{Q}$ Ubah $($ Hapus Selebihnya \\
\hline$\square 21$ & 21 status & $\operatorname{varchar}(100)$ & latin1_swedish_ci & & Ya & NULL & & 2 Ubah () Hapus Selebihnya $\mathbf{T}$ \\
\hline
\end{tabular}

Sumber: Hasil Penelitian (2019)

Gambar 6. Data Pendaftaran di Simpan pada MySQL

\section{(2) Implementasi Interface}

Aplikasi memiliki beberapa menu yang dirancang dengan bentuk antar muka (interface) sebagai berikut:

a) Implementasi Interface Website

1. Menu Login dan Menu Utama 
Menu yang pertama kali ditampilkan saat admin masuk ke website. Menu yang ditampilkan saat admin telah masuk ke website. Menu utama menampilkan beberapa menu seperti menu home, input berita, data pendaftaran, dan profile.
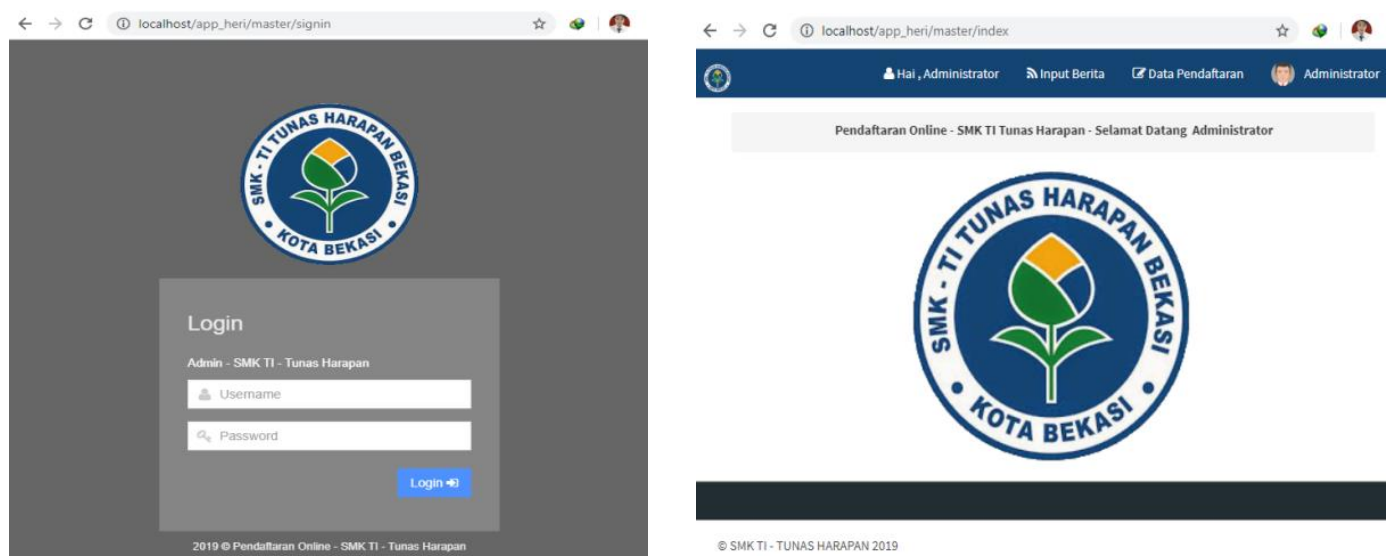

Sumber: Hasil Penelitian (2019)

Gambar 7. Implementasi Menu Login dan Menu Utama

2. Menu Data Pendaftaran

Menu yang menampilkan list data-data user atau data calon siswa/i untuk di seleksi pada menu proses.
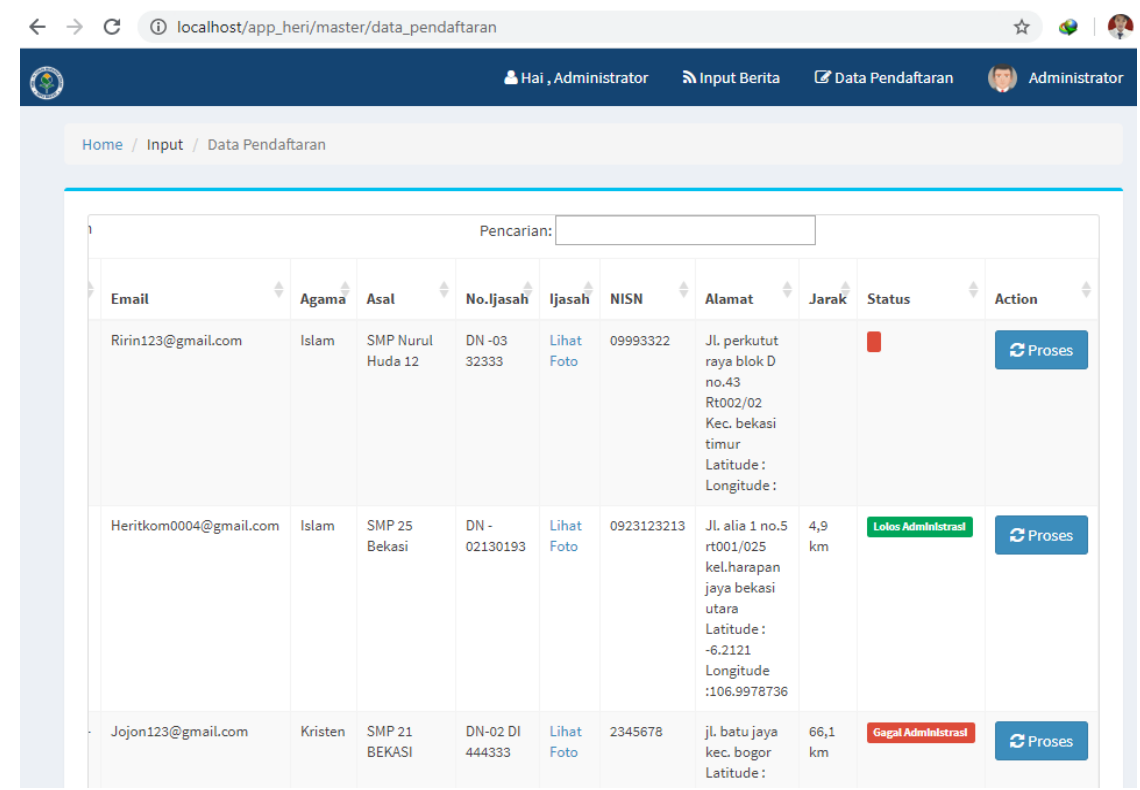

Sumber: Hasil Penelitian (2019)

Gambar 8. Implementasi Menu Pendaftaran

\section{Menu Proses}

Fungsi dari menu proses ini agar admin dapat melakukan seleksi dengan mengambil data latitude, longitude, dan data jarak. Pada basemap dalam website akan menampilkan titik user berada dalam radius beberapa KM dan dapat menampilkan rute. 


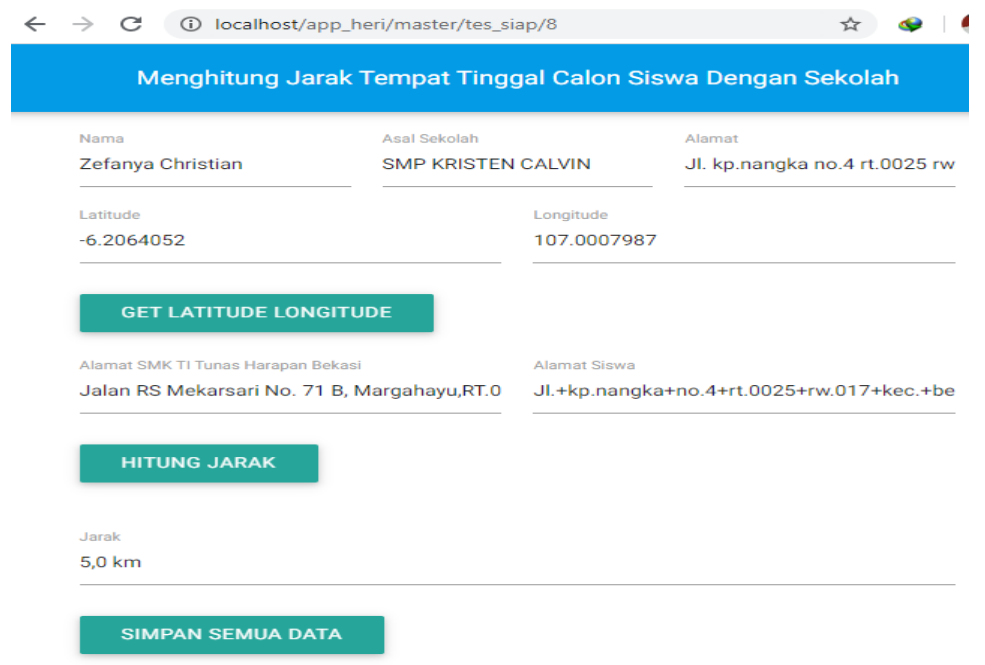

Sumber: Hasil Penelitian (2019)

Gambar 9. Implementasi Menu Proses

\section{b) Implementasi Interface Android}

1. Menu Registrasi dan Menu Login

Menu registrasi adalah menu yang pertama kali di tampilkan saat user masuk ke aplikasi android. Menu login adalah menu yang tampil bersama dengan registrasi setalah menekan tombol (login disini).

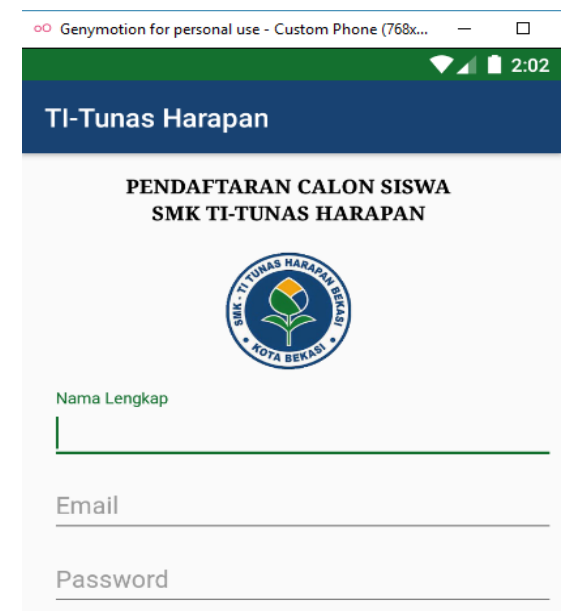

DAFTAR SEKARANG

SUDAH PUNYA AKUN ? LOGIN DIIINI :

$\triangleleft$
O

$\square$

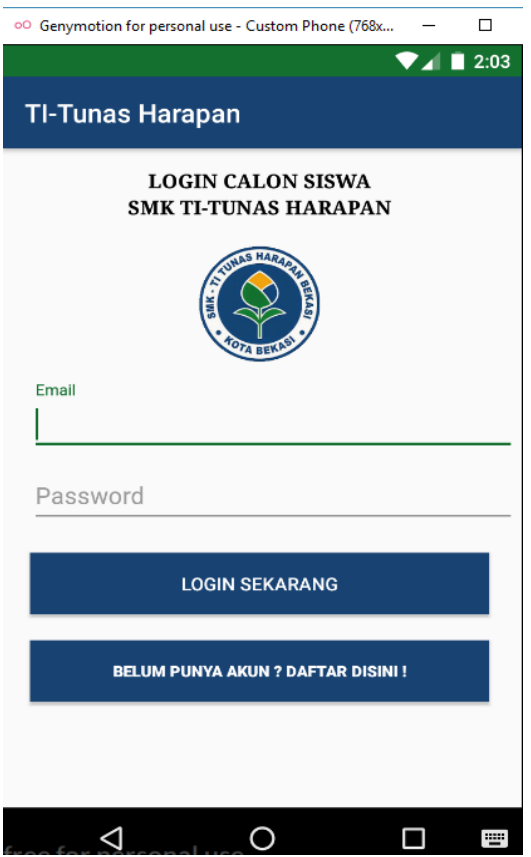

Sumber: Hasil Penelitian (2019)

Gambar 10. Implementasi Menu Registrasi dan Menu Login 
2. Menu Utama dan Menu Home

Menu utama adalah menu yang ditampilkan saat user telah masuk ke aplikasi. Menu utama menampilkan beberapa menu seperti menu home, berita, rincian biaya, pendaftaran online, pengumuman, dan logout. Menu home adalah menu yang menampilkan nama user dan informasi sekolah berupa visi dan misi.
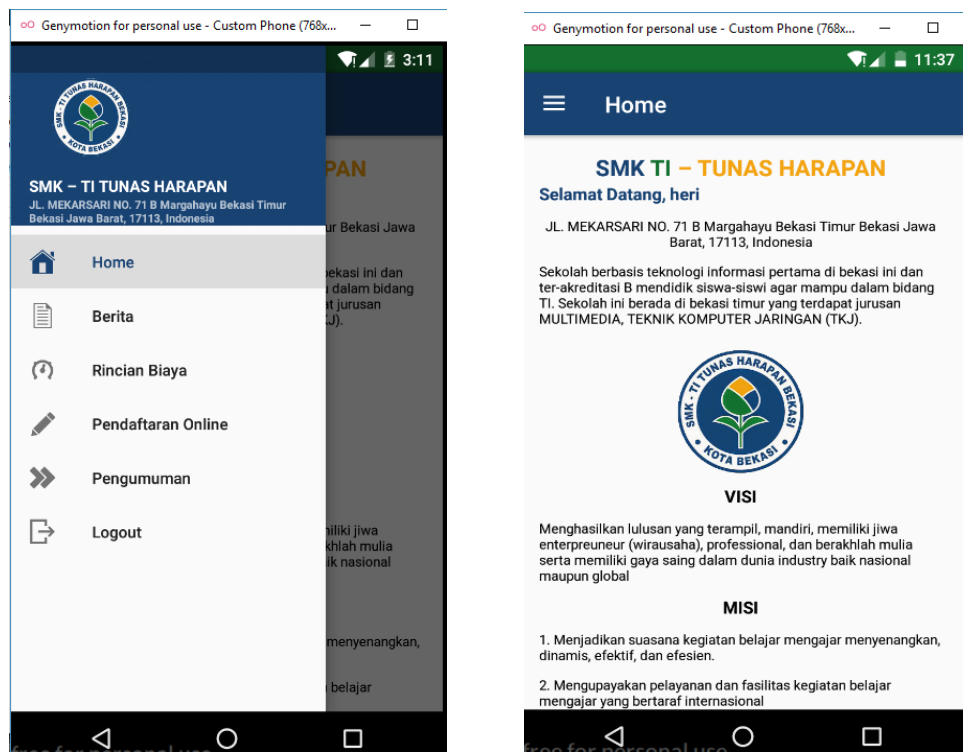

$$
\text { SMK TI - TUNAS HARAPAN }
$$
Selamat Datang, heri

JL. MEKARSARI NO. 71 B Margahayu Bekasi Timur Bekasi Jawa
Barat, 17113, Indonesia Sekolah berbasis teknologi informasi pertama di bekasi ini dan
ter-arkeditasi 8 m mendidids siswa-siswi garar mamp ud alam bidang Ter-akreditasi mendidik siswa-siswi agar mampu aalam bida
TIS Sekolah ini berada di bekasi timur yang terdapat jurusan
MULTIMEDIA, TEKNIK KOMPUTER JARINGAN (TKJ).

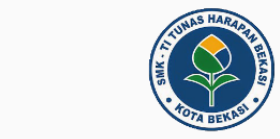

VISI

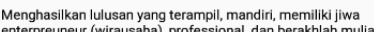
Menghasinneur (wirausaha), professional, dan berakhlah mulia
enterpreuneur serta memiliki gaya saing delem dunia industry baik nasional
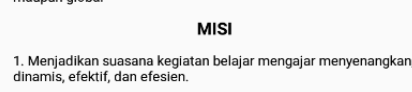

2. Mengupayakan pelayanan dan fasilitas kegiatan belajar
mengajar yang bertaraf internasional

4 O

$\Delta$

O

Sumber: Hasil Penelitian (2019)

Gambar 11. Implementasi Menu Utama dan Menu Home

3. Menu Rincian Biaya

Menu yang menampilkan biaya administrasi sekolah.

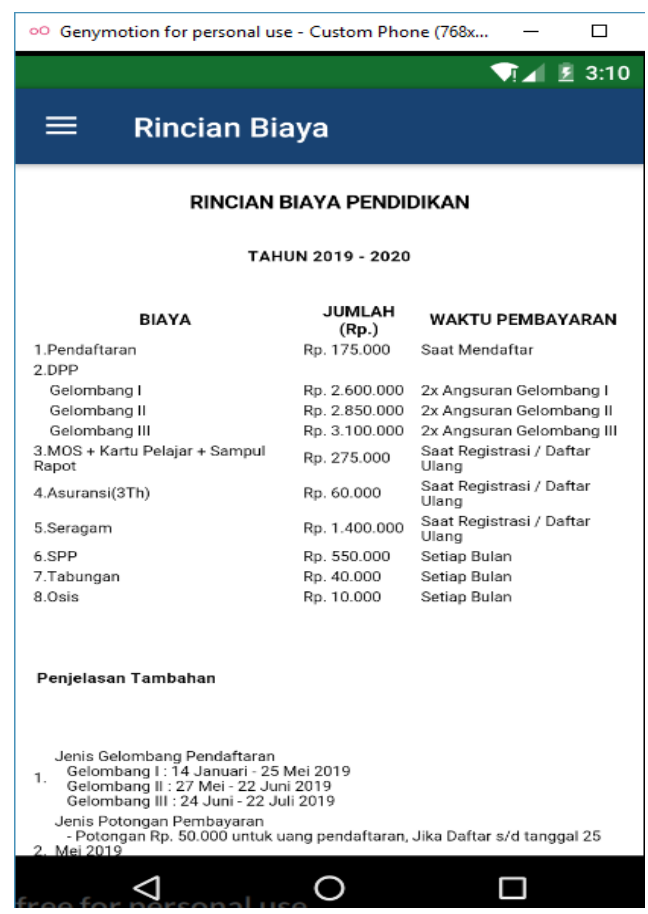

Sumber: Hasil Penelitian (2019)

Gambar 12. Implementasi Menu Rincian Biaya 


\section{Menu Pendaftaran Online dan Menu Pengumuman}

Menu Data Pendaftaran Online Ini Berisi Form Untuk Pendaftaran Calon Siswa Pada Sekolah. Menu ini menampilkan data user yang telah di seleksi oleh admin, dan menampilkan hasil dari seleksi berupa nama dan jarak KM dari sekolah.
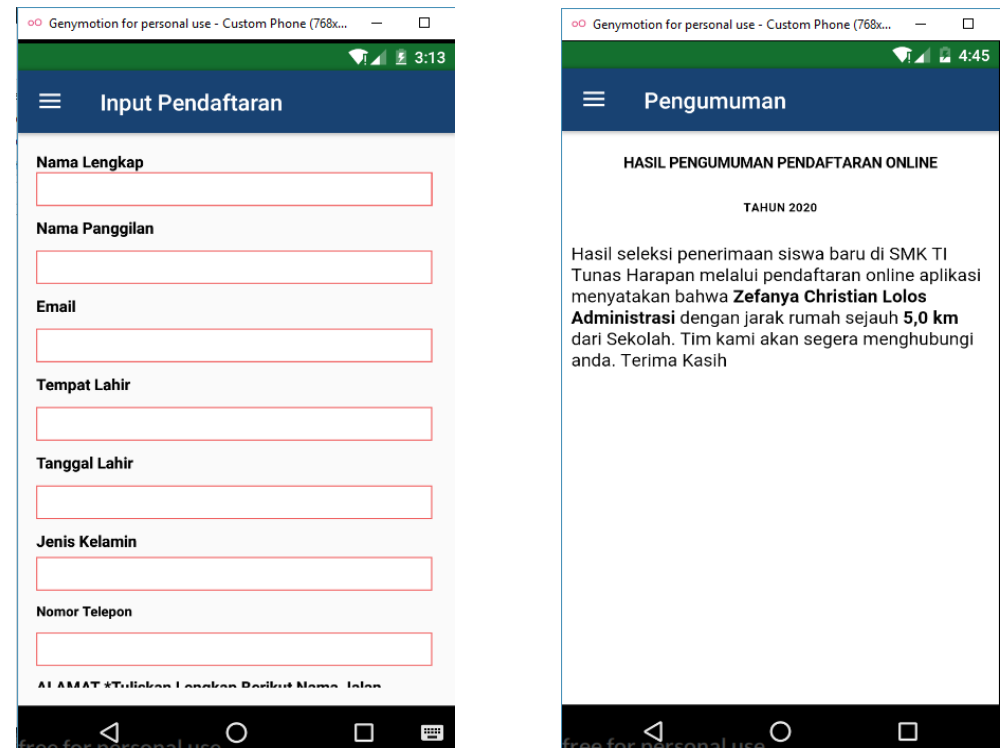

Sumber: Hasil Penelitian (2019)

Gambar 13. Implementasi Menu Pendaftaran Online dan Menu Pengumuman

\section{c) Pengujian Aplikasi}

Pengujian aplikasi dilakukan untuk mengetahui apakah aplikasi dapat berjalan dengan lancar pada berbagai kondisi yang berbeda. Aplikasi diuji dalam pengujian perangkat lunak di berbagai smartphone Android maupun IOS yang berbeda. Pengujian dilakukan dengan menjalankan berbagi fungsi seperti registrasi user, login, berita, rincian biaya, pendaftaran online, pengumuman, dan logout.

Adapun kelebihan yang terdapat dalam penelitian ini adalah sebagai berikut : a) Pada penelitian ini dihasilkan zonasi sekolah SMK TI - Tunas Harapan. b) Aplikasi dapat diakses kapan saja. c) Pada peta di website admin ditampilkan zonasi sekolah dan lokasi titik calon siswa/i berada.

Adapun kekurangan yang terdapat dalam penelitian ini adalah sebagai berikut: 1) Aplikasi hanya dapat digunakan jika terhubung dengan jaringan internet. 2) Tampilan menu website dan android masih butuh tahap perkembangan.

\section{Kesimpulan}

Dari hasil dan pembahasan pada penelitian ini, penulis dapat menyimpulkan bahwa: 1) Perancangan aplikasi pendaftaran online berdasarkan sistem zonasi adalah berbasis android yang dapat memetakan dan menentukan zonasi jarak sekolah dengan calon siswa/i dengan memanfaatkan beberapa filter pecarian seperti alamat, dan menentukan posisi user. 2) Telah 
dilakukan uji fungsional, pada aplikasi yang menunjukan bahwa aplikasi sudah berjalan dengan baik dan optimal. 3) Aplikasi yang dibangun memiliki manfaat sangat baik. Aplikasi juga dinilai sangat memudahkan masyarakat untuk menentukan zonasi sekolah. Saran yang dapat diambil dari hasil dan pembahasan penelitian ini sebagai berikut: 1) Penelitian yang dilibatkan kali ini masih bisa ditambahkan tidak hanya SMP saja tapi bisa seperti TK, SD, SMA atau SMK Negeri maupun Swasta. Berdasarkan faktor zonasi sekolah masih terdapat parameter lain yang berpengaruh. 2) Kecepatan loading pada aplikasi masih dapat ditingkatkan, salah satunya dengan penggunaan web map server. 3) Query data hasil pada aplikasi dapat diperkaya fungsinya, sehingga pengguna tidak terbatas melakukan query berdasarkan query radius.

\section{Daftar Pustaka}

Arif, A.H. (2013). 24 Jam Pintar Pemrograman Android. Yogyakarta: ANDI.

Erika, O.R, et all. (2016). Aplikasi Pencarian Letak ATM Berbasis Android Dengan GIS Di Kota Bandar Lampung. Jurnal Komputasi Vol. 4, No. 1, 2016

Februariyanti, H., \& Zuliarso, E. (2012). Rancang Bangun Sistem Perpustakaan untuk Jurnal Elektronik. Jurnal Teknologi Informasi DINAMIK Volume 17, No.2, Juli 2012: 124-132.

Hanadi, T.S. (2013). Perancangan Aplikasi Bisnis LapakMobile.com pada Pasar Tradisional Simpang Bandung Menggunakan PHP dan MYSQL berbasis Web. Bandung: Universitas Komputer Indonesia.

Juansyah, A. (2015). Pembangunan Aplikasi Child Trackerberbasis Assisted - Global Positioning System(A-Gps) Dengan Platform Android. ISSN: 2089-9033

Maharani, S, et all. (2017). Sistem Informasi Geografis Pemetaan Masjid di Samarinda Berbasis Web. Jurnal Informatika Vol. 11, No. 1, Jan 2017.

Nugroho. (2013). Dasar Pemograman Web PHP-MySQL Dengan Dreamweaver. Yogyakarta: Gava Media.

Sakur, S. (2011). PHP 5 Pemrograman Berorientasi Objek Konsep Dan Implementasi. Yogyakarta: Andi Offset.

Sukamto, R.A., \& Shalahuddin, M. (2013). Rekayasa Perangkat Lunak. Bandung: Informatika.

Wardhani, R., \& Yaqin, M.H. (2013). Game Dasar-Dasar Hukum Islam Dalam Kitab Mabadi'ul Fiqh Jilid I. Jurnal Teknika Vol. 5 No.2 September 2013: ISSN No. 2085 - 0859. 